\title{
Analysis of the Application of the Online Learning System (Spada) to Increase Student Learning Activities during the Covid-19 Pandemic
}

DOI: https://doi.org/10.47175/rielsj.v2i3.304

\section{| Oktaviandi Bertua Pardede ${ }^{1}$ | Nanda Dwi Astri²}

${ }^{1}$ FKIP, University of Prima Indonesia, North Sumatra, Indonesia.

${ }^{2}$ University of Prima Indonesia

${ }^{1}$ andiepard21@gmail.com

${ }^{2}$ nandadwiastri75@gmail.com

\begin{abstract}
This study aims to explore student learning activities at the Faculty of Teacher Training and Education, University of Prima Indonesia (Unpri) during the pandemic through Spada. This needs to be done because there are significant differences in the learning system. The transfer of face-to-face learning methods to virtual distance learning, namely Spada, triggers the emergence of a direct effect on student learning activities. This study applies a qualitative descriptive approach with survey methods and semi-experimental methods that apply hypothesis testing. The sampling technique used cluster random sampling with the research sample being Indonesian Language and Literature Education students who were at level 3. This sample was grouped into 4 parallel classes. Observations showed that student learning activities in Spada who consistently attended every meeting were $62.2 \%$. The survey also shows that $52.7 \%$ are interested in face-to-face learning. Students are known to often access lecture materials that are not in accordance with the time of admission. And a report on Spada shows that the average material access period lasts less than 20 minutes. Students tend to ignore the resources and learning activities implemented in Spada. The results of the questionnaire confirmed the existence of obstacles in student learning activities through Spada by $47.5 \%$. Researchers also attempted to conduct experiments on the assessment of learning outcomes through the one-way ANOVA test. The result is $p>0.05$ and shows the acceptance of $\mathrm{H}_{0}$ that there is no difference in student learning outcomes between classes. So it can be proven that the application of Spada has not been able to increase the learning activities of different students during the pandemic.

KEYWORDS;

application of Spada; learning activity; Covid-19 pandemic; learning outcomes services
\end{abstract}

\section{INTRODUCTION}

Human, the most complete and most advanced creature on earth, is the most powerless and the most helpless at birth and with the greatest talent is able to learn from their experience as best as possible and the responses and experiences learnt constitute his/her most behavioral reservoir (Bakhtiarvand, M. 2020). Education is the space scope of man's most harmed after the occurrence of a pandemic covid-19's. Functions that are so important to improve the civilization of man perceived decline after the implementation Out of Distance Learning (ODL). Most large force of educators, teachers and lecturers lose passion as a professional, because it does not exist any program of learning can be held in the to class 
shared student. All changed since enforced policy on the implementation of learning are determined by Nadiem Anwar Makarim namely the implementation of learning based on zones of colour. Until finally, set the rules the government number 21 in 2020 on the restriction of social scale large in order to accelerate the handling of covid-19, and the results are there lockdown in a period of time. One school year has been carried out without even meeting face to face in class. It is further compounded by the number of students who return to the area each thus causing difficulties to interact with the lecturer.

The use of the internet was not able inevitable again during a pandemic because of the learning that is applied by Unpri done via spada. It is certainly an impact on the activity of learning and behavioural learning students. Rosali (2020) have demonstrated that a pandemic Covid-19 affects the condition of psychological and change the behaviour of human beings whose nature is more extensive in the period of time that is long. Of course, this can be used as an illustration that the application of online learning during the pandemic has had an effect on students. Survey on knowledge of technology information based on the Internet that do the students Faculty of Teacher Training and Education Unpri showed that 95.5\% always use the internet in the activity of learning and the rest is still integrating the reference books to support the activity of learning and of $95.5 \%$ of the students that have behavioral passive for lecturers to apply learning online. Total of $85.5 \%$ of students that did not provide a response positively to the space of discussion that is applied by the lecturer. Of course, this is an early picture of the low student learning activity. As Uswatun (2020) obtain that the majority of problems psychological that experienced by the students in the process of learning online is anxiety. It's looks real because students often times to confirm any activity that they do, when the lecturer was giving an explanation beforehand about it.

In fact, learning activities can no longer be measured by looking directly at students in class. During the pandemic, the lecturers implement activities to learn it online have limited space of view and even some students Faculty of Teacher Training and Education also turn off the video conference at the time of learning virtual. It is indicates that the student is difficult to contribute to the system of learning this. Most major college students often just listen without participating intervene in the meeting that, in fact there are also students who at once did not follow the meeting it with a variety of reasons. As that expressed by Hamalik (2007) that should have been learning given the learners in the situation of learning that students participate actively during the lecturers teaching with heading an order to load the material that has been determined and set out in the curriculum can be achieved.

Although there are a variety of types of activities to learn as that expressed by Paul B. Diedrich in Sardiman (2010) that there are 8 kinds of activity learning students include visual activities, oral activities, listening activities, writing activities, drawing activities, motor activities, mental activities, emotional activities. But it seems it will be difficult to achieve with intact if learning just do it online via video conferencing. So based on policies that are set Kemendikbud enact programs spada to improve equitable access to learning that quality in education higher. And in the end, the management of learning in environments Faculty of Teacher Training and Education Unpri was enhanced further by applying spada Unpri.

Spada Unpri implement a Learning Management System to implement a page web with a feature presentation of the class (course) which is composed on the menu material teaching, matter and task. Martin Dougiamas, who has graduated in computer science and education, wrote the first version of Moodle. The beginning of test 's utility software is open-source it to support the epistemology of teaching and learning with the use of community that based internet. Along walk with a time criteria of the software is functioning as an e-learning (Weller, M. 2006). Spada to implement the package device lunar moodle (Modular ObjectOriented Dynamic Learning Environment) has been used by Unpri since mid-year 2019. The 
implementation of the activities of learning-based internet and web sites using the principle of social constructionist pedagogy becomes the basis of the chosen device is. Law of the Republic of Indonesia No. 20 year 2003 about System of Education National Article 31 also has set the ODL and the end time is the development of ODL has until the generation $4 \mathrm{~s} / \mathrm{d}$ 6 are models of learning felsibel with internet-based resource / Computer-Mediated Comm (CMC), a flexible intelligent with CMC correspondence / academic administration portal to generations with mobile learning .

At the beginning of the implementation of learning spada is in Faculty of Teacher Training and Education Unpri, actualy appear various obstacles were encountered, including: most large faculty and students do not understand the system/technology information spada, application of ODL with the spada deemed not relevant to the vision Faculty of Teacher Training and Education Unpri because it can decrease the skills of language students , there are still some lecturers who are not accustomed to using technology , and relatively little preparation. Sure constraints this may only differ in personal, considering the number of lecturers and students were pretty much. By reason that data research is obtained on the teachings of 2020/2021 half even, precisely in February 2021July 2021. The goal is that the data analysis in this study is truly reliable.

Since the initial introduction of spada in the teachings of 2019/2020 semester of odd precisely in September 2019, in fact professors and students have been mentored for one semester. Until finally in the teachings of 2019/2020 half even coincide enactment of Work From Home (WFH), the whole eye study should be managed through spada, although there disepensasi for some eye course special. Based on the information that is obtained from a team monitoring and evaluation Unpri, shows the graph increase in the number of posts and accessing the material of learning for some eye lectures in Faculty of Teacher Training and Education Unpri. There is a $80 \%$ eye study that shows activity spada are active, and the rest did not experience an increase significantly. Tim monev Unpri assume that regard it is very possible to happen because of the inconsistent lecturers in applying a source of learning and modes of activity in case spada at each meeting.

However, over the passage of time, seemed to start happening a decrease in the activity of learning a student at spada. Even the eyes of college is already managed by the well. During the covid-19 pandemic, it turned out that ODL through Spada was considered by students as an application that could be manipulated. Based on interviews with several professors Faculty of Teacher Training and Education Unpri, it seems most large student began not serious in follow spada. This can be proven by the decreasing duration of student access time on each meeting topic. Sure thing it needs to analyse the cause, so that based on the description in the above, the author has several objectives including: to determine the activity of learning a student during a pandemic covid-19, to determine the activity of learning of students through spada and to determine the effect of the use of spada during a pandemic covid-19. By reason that, the authors attempt to examine about the analysis of the application of the system of learning within the network (spada) to increase the activity of learning of students during a pandemic covid-19.

\section{RESEARCH METHODS}

This research uses a descriptive approach with survey and semi experimental methods. Both methods research is to realize the purpose of research, as Sugiyono (2013:27) states that the purpose of research that is different can be analysed by a method that is different. Cluster random sampling was used to determine the sample in this study and obtained 98 respondents who were in 4 parallel classes. Respondents are $6^{\text {th }}$ semester students majoring in Indonesian Language and Literature Education Faculty of Teacher Training and Education 
Unpri. Research conducted on the teachings of 2020/2021 half even by applying spada. Data were collected by using questionnaires and tests. The results are analysed by descriptive and tested by using independent sample $t$ test.

\section{RESULTS AND DISCUSSION}

After a year spada applied in Faculty of Teacher Training and Education Unpri, the actual activity of learning have not demonstrated an increase that significantly. It is to be understood as yet their provisions and rules to oblige learning online. So that the data research obtained on the teachings of 2020/2021 half even, with the purpose of getting the data are reliable. The survey results showed that there were 98 students who registered at the Unpri spada. All students who were sampled in the study were in level 6 and chose the education statistics course. Based on the data in one half obtained graph access (views) and the posting of students who are not consistent.

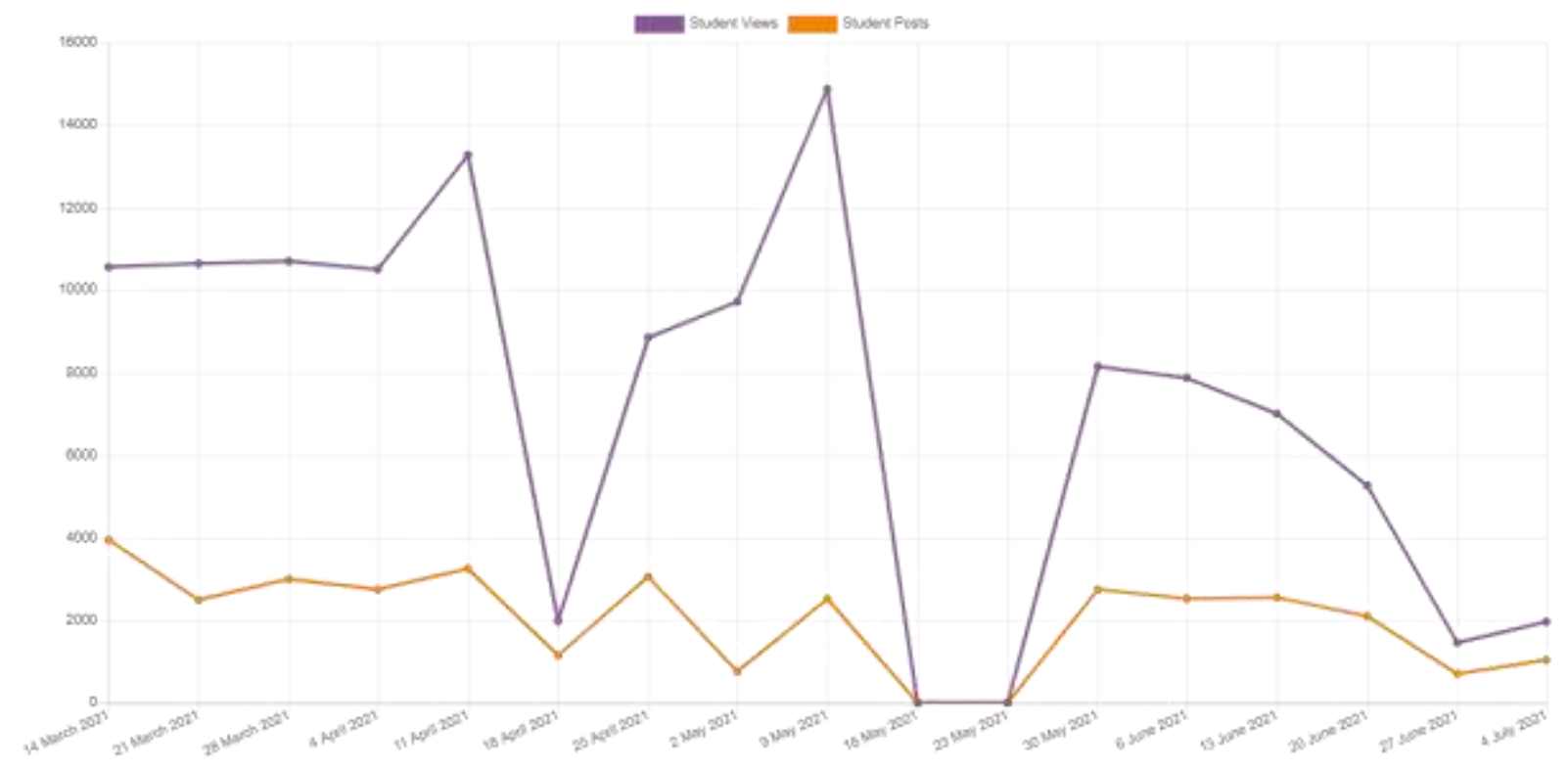

Figure 1. Graph of Student Activity at Spada Unpri

The number of students that should the frequency of access and posts are on the line curves are relatively the same. There are also student were late in clicking for lectures, and finally considered not present in the meeting. This can be known from the percentage of the number of attendance of students, namely:

Table 1. Number of Student Attendance

\begin{tabular}{cc}
\hline Number of Attendees & Percentage \\
\hline $\mathbf{< 1 2}$ & $0 \%$ \\
\hline $\mathbf{1 3}$ & $6,2 \%$ \\
\hline $\mathbf{1 4}$ & $5,1 \%$ \\
\hline $\mathbf{1 5}$ & $26,5 \%$ \\
\hline $\mathbf{1 6}$ & $62,2 \%$ \\
\hline Total & $100 \%$
\end{tabular}

Further secondly the data in the above associated with the results of a survey that is done to the students, and turns of fact $47.3 \%$ of students are interested to learn it online and $52.7 \%$ studied in face-to- face. Here are the details of the data results of the survey are: 
Table 2. Survey Type Learning that Attracts Students

\begin{tabular}{ccccc}
\hline Type of & \multicolumn{4}{c}{ Class ( Total / Percent ) } \\
\cline { 2 - 5 } Learning & Morning & Morning & Morning & \multirow{2}{*}{ Afternoon } \\
& $\mathbf{A}$ & $\mathbf{B}$ & $\mathbf{A}$ & \\
\hline Virtual & $8 / 29,6 \%$ & $17 / 53,1 \%$ & $13 / 48,1 \%$ & $7 / 58,3 \%$ \\
\hline Face to face & $19 / 70,4 \%$ & $15 / 46,9 \%$ & $14 / 51,9 \%$ & $5 / 41,7 \%$ \\
\hline
\end{tabular}

The researcher also gave a questionnaire to the students to find out the students' learning problems. In this case the items of the questionnaire statement are carried out in a closed manner with 4 criteria's, and the following are the results of the data obtained:

Table 3. Student Learning Constraint Questionnaire

\begin{tabular}{cccccc}
\hline \multirow{2}{*}{ Criteria } & \multicolumn{4}{c}{ Class ( Score / Percent ) } & \multirow{2}{*}{ TOTAL } \\
\cline { 2 - 5 } & Morning A & Morning B & Morning C & Afternoon & \\
\hline $\begin{array}{c}\text { Internet Network } \\
\begin{array}{c}\text { Concentration / Material } \\
\text { Comprehension }\end{array}\end{array}$ & $59 / 43.7 \%$ & $76 / 47.5 \%$ & $66 / 48.9 \%$ & $30 / 50.0 \%$ & $231 / 47.1 \%$ \\
\hline Internet Quota & $64 / 47.4 \%$ & $78 / 48.8 \%$ & $68 / 50.4 \%$ & $31 / 51.7 \%$ & $241 / 49.2 \%$ \\
\hline $\begin{array}{c}\text { Learning Resources and } \\
\text { Activities }\end{array}$ & $55 / 40.7 \%$ & $68 / 42.5 \%$ & $60 / 44.4 \%$ & $25 / 41.7 \%$ & $208 / 42.4 \%$ \\
\hline TOTAL & $252 / 46.7 \%$ & $303 / 47.3 \%$ & $262 / 48.5 \%$ & $114 / 47.5 \%$ & - \\
\hline
\end{tabular}

In the end, learning outcomes are also measured to determine the effectiveness of learning activities through this spada. The data is taken from the value of the final examination which is carried out online via Spada, here are the results:

Table 4. Description of Student Learning Outcomes

\begin{tabular}{|c|c|c|c|c|c|c|c|}
\hline \multirow{2}{*}{ Class } & \multirow{2}{*}{$\mathbf{N}$} & \multirow{2}{*}{ mean } & \multirow{2}{*}{$\begin{array}{c}\text { Std. } \\
\text { Deviation }\end{array}$} & \multicolumn{2}{|c|}{$\begin{array}{l}\text { 95\% Confidence Interval } \\
\text { for Mean }\end{array}$} & \multirow{2}{*}{ Minimum } & \multirow{2}{*}{ Maximum } \\
\hline & & & & $\begin{array}{l}\text { Lower } \\
\text { Bound }\end{array}$ & $\begin{array}{l}\text { Upper } \\
\text { Bound }\end{array}$ & & \\
\hline Morning A & 27 & 46.5522 & 14.84663 & 40.6791 & 52.4254 & 0.00 & 77.78 \\
\hline morning B & 32 & 51.3884 & 9.60279 & 47.9263 & 54.8506 & 36.11 & 75.00 \\
\hline Morning C & 28 & 50.6439 & 11.45599 & 46.2018 & 55.0861 & 22.22 & 69.44 \\
\hline Afternoon & 11 & 56.2145 & 21.11713 & 42.0279 & 70.4012 & 33.33 & 97.22 \\
\hline Total & 98 & 50.3850 & 13.39216 & 47.7000 & 53.0700 & 0.00 & 97.22 \\
\hline
\end{tabular}

By watching images 2 can be known that the value of the average Final Semester Examination are in under 60.00. The distribution of the data in Figure 2 is also influenced by the variance of the grades for each class, and it turns out that the extreme values are in the morning A and afternoon classes, namely in each class there are students who get the lowest and highest scores. 


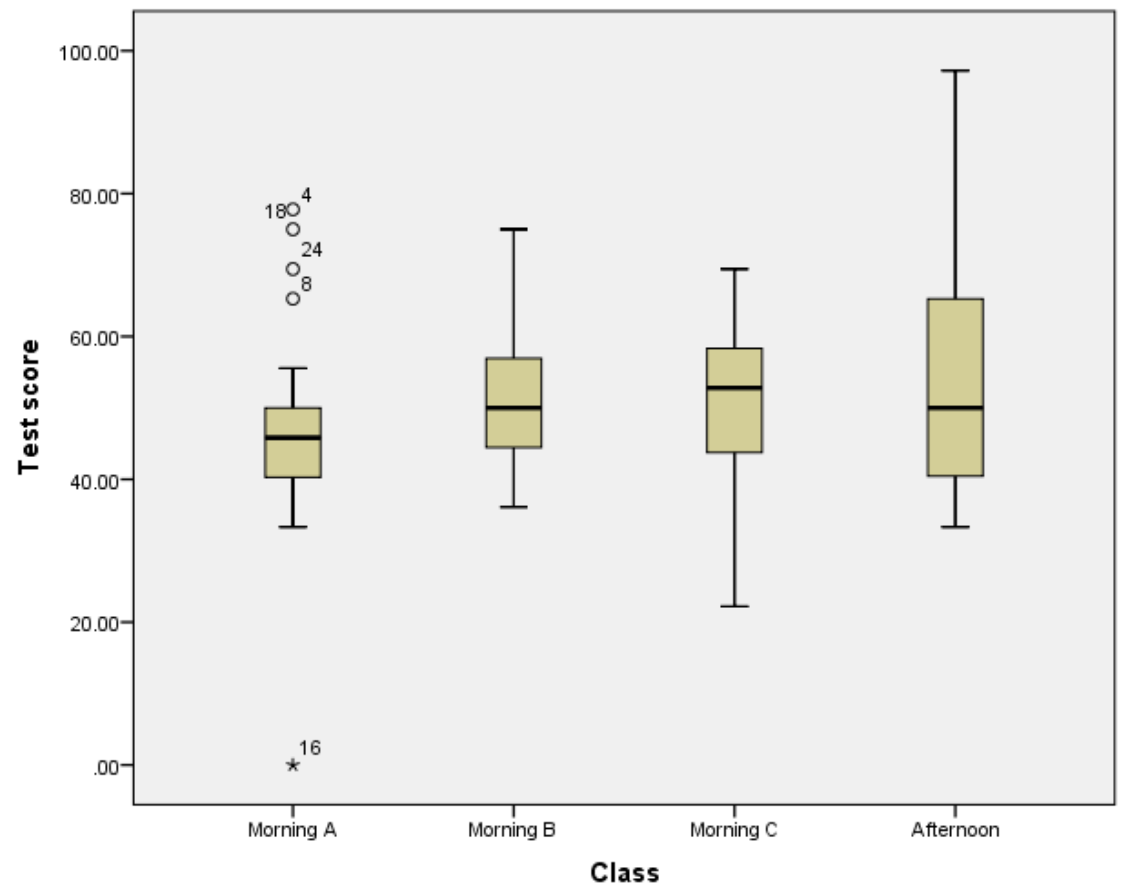

Figure 2. Description of the Difference in Final Semester Examination Values

Results of study on top then tested by using a test anava one lane to know the differences in the effects of the activity of learning students via spada. And the following are the results of data analysis through SPSS version 20.

Table 5. Analysis of Variance through F test

\begin{tabular}{cccccc}
\hline & Sum of Squares & df & Mean Square & F & Sig. \\
\cline { 2 - 6 } Between Groups & 804.552 & 3 & 268,184 & 1.519 & 0.215 \\
Within Groups & 16592.406 & 94 & 176.515 & & \\
Total & 17396,958 & 97 & & & \\
\hline
\end{tabular}

Based on table 5, it is known that $\mathrm{p}=0.215$ and when compared with the probability value, the price of $\mathrm{p}>0.05$. That is, hypothesis testing resulted in the acceptance of $\mathrm{H}_{0}$, that is there is no difference in learning outcomes through Spada. So with such application spada not show any difference in the increase in the activity of learning that is significant. The results of this gives an overview of the application of spada which has been carried out during the year before turned out to show an increase in the result of learning the same. This means, the activity of learning through spada give the impact that each of the outcomes of learning. Even though Nasrah's research (2020) shows that online learning during a pandemic can increase learning activities. So that online learning during the covid-19 pandemic has flexibility in its implementation and is able to encourage the emergence of independent learning and motivate students to be more active in learning (Firman \& Rahayu, 2020)

If you refer to the research of Barber, $\mathrm{H}$ (2020) that there is an understanding to accept technology as a learning tool during online learning can be one of the factors of difficulty in the student learning process. Factors other is the use of applications such as zooming cloud meetings, classroom google, youtube, whatsapp is considered to increase the activity of learning students (Deno, Kalaka \& Harso, 2020). So by learning spada are applied in Faculty of Teacher Training and Education Unpri, the actual activity of learning students need to 
collaborate during a pandemic in order to increase interest in learning the students are online. Especially when the application lockdown, it is necessary the search of the destination primary learning by designing the activity of learning that can be optimized in line during a pandemic ( van der Velde, M., Sense, F., Spijkers , R., meeter , M., \& van Rijn, H. , 2021) . By reason that, the management of the activity studied in spada Unpri need to be designed with attention to the situation of the pandemic that occurred.

Although the results of study in research is relatively low in value an average of 50.39, things have not become a starting measuring indicators of the low activity of learning that is applied in spada. The difficulty level of the courses is also an indicator of the low student learning outcomes. Based on the results of research Maulana \& Iswari (2020) find that high levels of stress experienced by students in the eyes of course this is due to the intensity of thought critical for learning online. Even the use of online teaching materials that have been implemented at the Open University has not been maximized, the results of research by Lestari, E.P., Nupikso, G., \& Riyani , E.I. (2015) show that there is a need for the intensity of using online teaching materials contained in online tutorials to improve student achievement .

A concept about the transformation of education was becoming one of the solutions to increase the activity of learning. Ng, C., \& Renshaw, P. (2020) conclude that school curricula, knowledge culture and family practices must transform each other in learning. Each activity learning students seem to need to assimilate the conditions that are relevant in the pandemic's. Vladova, G., Ullrich, A., Bender, B., \& Gronau, N. (2021) provide reviews that students need to accept the mediation of technology in learning, by watching the flexibility of time, the flexibility of learning and isolation social. So that the value of the acquired student FKIP Unpri during a pandemic does not show an increase in the results of study were significant.

\section{CONCLUSION}

Research data were obtained from activity learn student for one semester of this turned out to not give the impact that positive. Implementation spada looks not be provide motivation to learn the students and stuff it can be demonstrated through the value of the average test are low. The increase in learning activities during the pandemic is actually not always measured by achievement/ learning scores. The research discussion shows the need for a transformation of student learning evaluations such as applying assessments based on affectivity. Implementation spada also need to assimilate the various mediation technology to increase the activity of learning of students, such as the application of video recording learning, video conferencing, online chat and video calls. So the way thus, the destination face to face study can be achieved by optimal.

This research also provides a new picture of learning innovation. Every eye lectures will be increasingly accommodated to create the findings of new about the strategy of learning in the pandemic's. So as to thus, transfer of activities to learn the pandemic period this will result in the strengthening and opportunities to improve the management of spada. Management of learning face to face also will be affected as a result of the transfer system of learning is online this. Until the end, the activity of learning the students also become so complex when arranged in the Draft Education Semester.

Results of studies have demonstrated that the activity of learning a student is getting decreased. The average time accessing each student only reached 20 minutes alone, and the rest of the time more much used to doing quizzes or assignments that exist in spada. Research is clearly showing that it was not any difference in the results of study are significant, 
because the managing spada are less optimal. By reason that, lecturers need to undertake the elaboration of learning through technology.

\section{REFERENCES}

Baber, H. (2020). Determinants of Students' Perceived Learning Outcome and Satisfaction in Online Learning during the Pandemic of COVID19. Journal of Education and ELearning Research, 7(3), 285-292. https://doi.org/10.20448/journal.509.202 0.73.285.292

Bakhtiarvand, M. (2020). The Impact of Using Online Educational Tools on Science Learning among Students. Randwick International of Education and Linguistics Science Journal, 1(2), 107-113. https://doi.org/10.47175/rielsj.v1i2.78

Bertrand, L., Shaw, K. A., Ko, J., Deprez, D., Chilibeck, P. D., \& Zello, G. A. (2021). The impact of the coronavirus disease 2019 (COVID-19) pandemic on university students' dietary intake, physical activity, and sedentary behaviour. Applied Physiology, Nutrition, and Metabolism, 46(3), 265-272.

Deno, M. E., Kaleka, M. B. U., \& Harso, A. (2020). AKTIVITAS BELAJAR MAHASISWA PROGRAM STUDI PENDIDIKAN FISIKA UNIVERSITAS FLORES PADA MASA PANDEMIK CORONA VIRUS DISEASE 19. OPTIKA: Jurnal Pendidikan Fisika, 4(2), 110-116.

Hasanah, U., Ludiana, I., \& PH, L. (2020). Gambaran psikologis mahasiswa dalam proses pembelajaran selama pandemi COVID-19. Jurnal Keperawatan Jiwa, 8(3), 299-306.

Lestari, E. P., Nupikso, G., \& Riyani, E. I. (2015). Pengaruh penggunaan bahan ajar online terhadap prestasi mahasiswa Universitas Terbuka. Jurnal Pendidikan Terbuka Dan Jarak Jauh, 16(1), 1-9.

Maulana, H. A., \& Iswari, R. D. (2020). Analisis Tingkat Stres Mahasiswa Terhadap Pembelajaran Daring Pada Mata Kuliah Statistik Bisnis Di Pendidikan Vokasi. Khazanah Pendidikan, 14(1).

Nasrah, N., \& Muafiah, A. M. A. (2020). Analisis Motivasi Belajar Dan Hasil Belajar Daring Mahasiswa Pada Masa Pandemik Covid-19. JRPD (Jurnal Riset Pendidikan Dasar), 3(2), 207-213.

Ng, C., \& Renshaw, P. (2020). Transforming pedagogies in Australian schools amid the COVID-19 pandemic: An activity theoretic reflection. Best Evid Chin Edu, 5(2), 635648.

Oemar Hamalik. (2007). Dasar-Dasar Pengembagan Kurikulum, Bandung, PT Remaja Rosdakarya

Government Regulation No. 21 year 2020 Pembatasan Sosial Berskala Besar Dalam Rangka Percepatan Penanganan Coronavirus Disease 2019 (COVID-19) (Lembaran Negara Republik Indonesia Tahun 2020 Nomor 91, Tambahan Lembaran Negara Republik Indonesia Nomor 6487)

Rosali, E. S. (2020). Aktifitas Pembelajaran daring pada masa pandemi covid-19 di jurusan pendidikan geografi universitas siliwangi Tasikmalaya. Geosee, 1(1).

Republik Indonesia. (2013). Undang-Undang Sistem Pendidikan Nasional No 20 tahun 2003. Sekretariat Negara. Jakarta

Sardiman. (2010). Interaksi dan Motivasi Belajar Mengajar. Jakarta: Rajawali Pers. 
van der Velde, M., Sense, F., Spijkers, R., Meeter, M., \& van Rijn, H. (2021). Lockdown learning: Changes in online study activity and performance of Dutch secondary school students during the COVID-19 pandemic.

Vladova, G., Ullrich, A., Bender, B., \& Gronau, N. (2021). Students' acceptance of technology-mediated teaching-how it was influenced during the COVID-19 Pandemic in 2020: A Study From Germany. Frontiers in Psychology, 12, 69. https://spada.kemdikbud.go.id 